BAHTERA: Jurnal Pendidikan Bahasa dan Sastra, Volume 17 Nomor 1 Januari 2018 http://journal.unj.ac.id/unj/index.php/bahtera/

P-ISSN : 0853-2710

E-ISSN : 2540-8968

\title{
FOSTERING COLLEGE STUDENT'S CRITICAL READING SKILL THROUGH PADLET APPLICATION
}

\author{
VinaNurviyani \\ Suryakancana University \\ vinanurviyani@unsur.ac.id
}

\begin{abstract}
Critical reading is an essential skill for college students' success in academic and social engagement. Many students have troubles in reading the required books or references in some courses. Thus, this study aimed to investigate the effectiveness of padlet application as an instructional media in fostering college students' critical reading skill in higher education. Moreover, the strengths and the weaknesses of the padlet application in teaching critical reading were explored. This study applied action research was conducted in two cycles and involved twenty five college students. It was carried out at a private university in West Java. Moreover, three data collection techniques were applied in this study including reading tests, classroom observations, and questionnaire. The finding shows that by implementing padlet application in fostering college students' critical reading skill covering questioning, discussing, interpreting, summarizing and synthesizing, in the first cycle, most college students' critical reading skill achieved much improvement obviously. Sixty percents of all students reached the learning outcomes in critical reaading. Furthermore, in the second one, after carrying out a deep analysis and remedial teaching, eighty percents of them reached the learning outcome in critical reaading. It means that almost all college students' critical reading skill increased significantly. Thus, the implementation of padlet application in fostering students' critical reading skill is effective with the result showing significant difference, compared with that of the first cycle.
\end{abstract}

Keywords: action research, critical reading, padlet application.

\section{INTRODUCTION}

Reading is one of strands in literacy. Reading research has been conducted over decades beginning from L1 reading research until EFL reading or reading research of $\mathrm{L} 2$. By the end of twentieth century, one of focuses of L2 reading research investigated reading product and reading process. The research of reading product explores the readers' understanding in reading texts. Meanwhile, the studies of reading process examine whether or not the text is worth. Moreover, the reading process refers to the interaction between readers and a text, and the process of what readers can get as the meaning of a text. Besides, the decoding symbols, meaning negotiation, and thinking about reading difficulties or ease are investigated in research of reading process.

Critical reading is part of reading process. It is analytic process. It can help students become better readers and thinkers because they will be looking at reading as a process rather than a product. In this case, when they are reading, they are thinking and analyzing the text at similar time to identify information and to gain good understanding (Wallace, 2003; Yu, 2015). Many studies have been conducted to explore critical reading in different aspects, such as the analysis of critical reading ( $\mathrm{Yu}, 2015$;

BAHTERA : Jurnal Pendidikan Bahasa dan Sastra, Volume Januari 2018 
Zabihi\&Pordel, 2011), conceptual framework for teaching critical reading (Marschall\& Davis, 2012), being critical readers (Green \&Skukauskaite, 2008), etc. However, the research of critical reading investigating the effectiveness of digital devices is still new. Therefore, the study exploring the effectiveness of padlet application, the strengths and the weaknesses of padlet application in fostering students' critical reading skill in higher education is significant to carried out.The findings of this study are expected to contribute to development of critical reading theory and provide information for educators in implementing padlet application as a digital instructional media in fostering critical reading.

In underpinning this study, some theories were applied, they were the theory of literacy, critical reading, and multimodal literacy. Each theory is explain in detail below,

\section{Literacy and Critical Reading}

Literacy is defined much more than reading and writing. It is the ability to encode, decode, use, understand, and create a text to communicate in a variety of situations, and for numerous purposes in either verbal or non-verbal communication such as gesture, sounds and body language (Makin and Whitehead, 2004; Wallace, 2003). However, literacy is viewed as a critical arena of cultural and social power requirring a broader discourse competence that involves the ability to interpret and critically evaluate a wide variety of written and spoken texts(Emilia, 2010).

Literacy theory covers pedagogy (CP), critical literacy (CL), and critical thinking (CT). CP attempts to help people develop their critical consciousness towards the socio-cultural reality (Mochinsky, 2008; Reid, 2012). In other word, CP can be recognized as the use of texts in active and reflective manner in order to comprehend, analyze and transform unequal and injustice power of political, social, and cultural relationship (Morgan, 1997). Meanwhile, the term of critical literacy (CL) is taken from critical social theory of Frankfurt school in the mid 1980s (Morgan, 1997).In $\mathrm{CL}$, literacy is not only about making meaning with language, but it also plays as a critical basis of participating actively in the social field. The CL has some basic principles. The basic principles of CL are divided into two parts, namely: basic principles of CL based on critical social theory of literacy, and basic principles of CL based on CP. Regarding critical thinking (CT), it is thinking that explicitly aims at well-founded judgments and hence utilizes appropriate evaluative standards in the attempt to determine the true worth, merit or value of something (Chaffee, 2002).

The implementation of literacy based on the literacy theory includes reading and writing activities in classroom. CT in reading, it has a very close relation with reading since $\mathrm{CT}$ is the essential tool to analyze and to infer the texts. In other word, critical reading is CT that is applied to the process of reading (Cahffee, 2002). Before implementing critical reading through $\mathrm{CT}$ in the classroom, teachers should understand the principles of teaching $\mathrm{CT}$. the principles cover: (1) promoting interaction among students as they learn - learning in group setting helps each group member achieve more; (2) asking open ended questions; (3) allowing sufficient time for students to reflect on questions asked or problem posed; and (4) providing opportunities for students to see how a newly acquired skill can apply to other situation and to student's 
BAHTERA: Jurnal Pendidikan Bahasa dan Sastra, Volume 17 Nomor 1 Januari 2018

http://journal.unj.ac.id/unj/index.php/bahtera/

P-ISSN : 0853-2710

E-ISSN : 2540-8968

experiences (Wallace, 2003). The further discussion of critical reading is explored in detail in the next section.

Critical reading is a technique for discovering information and ideas within a text. It is a process to elicit meaning from a text by referring to a careful, active, reflective, analytic reading. The student who possesses good critical reading skills is able to go beyond the information given by asking questions, making hypotheses, seeking evidence, and validating assumptions (Marschall, 2012). Moreover, critical reading goes two steps namely having recognized what a text says, it reflects on what the text does by making such remarks, offering examples, arguing, appealing for sympathy, making a contrast to clarify a point, and inferring what the text, as a whole, means, based on the earlier analysis (Kurland, 2000).

\section{Multimodal Literacy}

Regarding the implementation of literacy in classroom, Jewitt (2005) explain that multimodal literacy is about understanding the different ways of knowledge representations and meaningmaking, such as on advertisements, posters, web-pages and films. Moreover, multimodal literacy focuses on the design of discourse by investigating the contributions of specific semiotic resources, (e.g. language, gesture, images) co-deployed across various modalities (e.g. visual, aural, somatic), as well as their interaction and integration in constructing a coherent multimodal text (such as advertisements, posters, news report, websites, films). The multimodal approach takes into account how linguistic and visual (and other) choices fulfill the purposes of the text, the audience and context, and how those choices work

together in the organization and development of information and ideas. 2.3.Padlet

Many instructional media have been implemented in teaching critical reading. In digital era, internet is a proper place to practice critical reading skill. In this case, internet is an attractive instructional media encouraging students to gain and publish much information (Walz, 2001). There are many applications of internet that can be applied in teaching critical reading. One of them is padlet (www.padlet.com).

Padletis a website for creating a buletin board that can be used for any kinds of learning. It is a digital application providing a free, multimedia wall which can be used to encourage students to take part and get assessment in teaching-learning process. The mode can be text, visual, sound, etc. On the wall the students can read something and post their ideas or share the ideas with their friends from the whole class. It provides online learning experiences. Moreover, padlet is a useful tool in the information literacy classroom. It works on a variety of different devices, does not require participants to create accounts to use it, and requires no special technical knowhow.

The implementation of Padlet can be done by going to padlet.com and register. Then click on "Create something." Your wall is now ready for use. In this case, you may conduct some modifications to it, such as giving it a title, changing the background image, giving your wall a unique web address, changing the display of posts, or choosing your wall's level of privacy. Students can contribute to your wall by going to the web address for the wall and then double clicking or, if using a mobile device, touching the wall to open up a box. Within that box, students can type, paste 
BAHTERA: Jurnal Pendidikan Bahasa dan Sastra, Volume 17 Nomor 1 Januari 2018 http://journal.unj.ac.id/unj/index.php/bahtera/

P-ISSN : 0853-2710

E-ISSN : 2540-8968

links, add audio or video clips, drag documents, and take pictures with their devices' built-in cameras. Contributions to the wall occur in real-time, so everyone can see when anyone else is adding something to the wall. You have several options for exporting wall contributions, and Padlet embeds very nicely. Moreover, you can create a Padlet account to access walls that you have created, and the content of the walls remains there indefinitely.

\section{METHODS}

Classroom action research plays an important role in the success of teachinglearning processes. The classroom action research is divided into three major stages namely: the first is finding a problem and making a preliminary investigation; and the second is forming a hypothesis and taking a number of strategies for improvement action; the third is reviewing and evaluating the results and running aworkshop for discussion. After that, the action research goes on a new cycle in which the teacher reflects on, returns to, and extends the initial inquiry (Nunan, 2002: 18). Relevant to the theory, this study applied classroom action research conducted in two cycles. This study was conducted to find out the effectiveness padlet application as an instructional media to improve students' critical reading skill. Besides, the strengths and the weaknesses of the application implemented to improve students' critical reading were explored.

In the first cycle, the classroom action research was begun by stating the problem and conducting preliminary investigation. The problem was students had less capability in critical reading skill so they had some troubles in reading the required books or references in some courses. In this stage, the researcher

designed teaching methodology and prepared all documents and devices needed for teaching critical reading by using padlet application. Next, the students were recognized to padlet application. Then they got the padlet link in which they could participate in critical reading process. Besides, they learnt how to take part in teaching-learning process of critical reading by using padlet application. In addition, the students tried to answer some question based on the text presented on padlet wall and then wrote their answer on the comment colom in the padlet application. Afterword,the students and the lecturer discussed it together.

The second stage was conducted as the improvement actions. This stage was the moment that the students learnt critical reading through padlet application. It was carried out in two meetings. The materials of critical reading were prediction and inference of factual texts. In this case, the students read some factual texts presented in multimodal text, consisting of written text and visual image. The teaching-learning activities in critical reading covered three steps, namely pre-reading, while reading, and post reading as recommended by Alderson \& Bachman (2000), Marschall \& Davis (2012), and Yu (2015). In the stage of pre-reading or before reading, the students identified the purpose and type of reading by focusing on factual texts. Next, in the stage of while reading, the students' activities covered questioning, discussing, interpreting, summarizing and synthesizing reading materials. In detail, they explored the general features of factual text, such as finding out a topic sentence of factual text, scanning the factual text to discover the detail information in supporting the topic sentence, projecting the author's purpose of factual text, and making continuous

BAHTERA : Jurnal Pendidikan Bahasa dan Sastra, Volume Januari 2018 
BAHTERA: Jurnal Pendidikan Bahasa dan Sastra, Volume 17 Nomor 1 Januari 2018 http://journal.unj.ac.id/unj/index.php/bahtera/

P-ISSN : 0853-2710

E-ISSN : 2540-8968

BAHTERA

predictions about what will happen next in the text. In last stage, post-reading, students commonly attempted to form a summary or conclusion or to make inferences of what had been read concerning factual text. Afterward, after teaching-learning process of critical reading by implementing padlet application, the students got a reading test to measure their achievement in critical reading skill. The reading test was conducted by using padlet application.

The last stage was reviewing and evaluating the results. This stage was conducted after all data gained completely. It was conducted to evaluate the effectiveness of padlet application implemented as the instructional media in teaching-learning process of critical reading. If the target had not been achieved significantly, the second cycle of the classroom action reasearch had to be conducted.

The second cycle of the classroom action research was carried out in similar stages namely a) finding the problem and making a preliminary investigation; b) forming a hypothesis and taking a number of strategies for improvement action; and c) reviewing and evaluating the results. Concerning the second cycle of the classroom action research, the first stage, the problem was based on the achievement of students in critical reading skill in the first cycle. In the second stage, the teaching methodology was designed in different way and remedial teaching-learning process of critical reading by applying padlet application was conducted to improve students' achievement in critical reading skill. In the last stage, the students got remedial test of critical reading presented in similar material, factual text, but in different text.

In conducting classroom action research, this study applied some data collection techniques covering reading tests, classroom observations, and questionnaire. Regarding reading tests, it was implemented to find out the effectiveness of padlet application in fostering students' critical reading skill. By implementing reading tests, the learning objective of the critical reading can be measured accurately. The reading tests were conducted twice by using similar material but in different evaluation, namely in the first and second cycle. The reading tests were posed to students at the end of second stage of each cycle. Each test of critical reading was held for ninety minutes.

Concerning classroom observations, it was conducted for four meetings, namely twice in each cycle. In this case, the researcher positioned herself as a teacher who immediately saw and heard what was happening as recommended by Thomas (2003: 60). It means that in this study the researcher observed what was going on during the teaching-learning process of critical reading by applying the padlet application. The researcher also interacted with participants during the teachinglearning process of critical reading.

Regarding questionnaire, it was written instrument present respondents with a series of questions or statements to which they are to react either by writing out their answers or by selecting from among existing answers (Dornyei, 2003: 6; Thomas, 2003). Relevant to the statements, this study employed open-ended questionnaires. The students got the questionnaire at the end of the second cycle. In this case, the participants answered ten questions having no options in each question. Besides, they had to fill the blank space (see Dawson, 2010: 31; Dornyei, 2007: 107). It intended to give them very free answer as proposed

BAHTERA : Jurnal Pendidikan Bahasa dan Sastra, Volume Januari 2018 
by Labaw (1980: 131). Besides, to make the students free in expressing their ideas and comprehend the questions more easily, the questionnaires were presented in Indonesian.

All data collection techniques were applied to answer all research questions, namely the effectiveness of padlet application to foster college students' critical reading skill, and the strengths and the weaknesses of the padlet application in teaching critical reading. Moreover, the participants involved in each data collection technique were twenty five college students of English department coming from a private university in West Java, Indonesia. Furthermore, the data gained from reading tests, classroom observations, and questionnaire were analyzed, categorized, and then interpreted into two categories based on the research questions.

\section{RESULTS AND DISCUSSION}

This study implemented three stages of classroom action research. The classroom action research consisted of two cycles. The stages of the classroom action research cover stating problem and making a preliminary investigation, forming a hypothesis and taking a number of strategies for improvement action; and reviewing and evaluating the results as proposed by Nunan (2002). Moreover, this study employed three data collection techniques including reading tests, classroom observations, and questionnaire.

Regarding the first research question concerning the effectiveness of padlet application in fostering students' critical reading, the data gained through reading test in the first cycle, the findings show that the implementation of the padlet application had fostered college students' critical readings skill. It can be seen from their achievements in critical reading test that had improved obviously. However, it had not been significant. Sixty percents of all students reached the learning outcomes. Many of their scores in critical reading was more than eighty but many of them got less than eighty. Referring the data obtained from the classroom observations, the results show that most students had trouble in integrating the meaning between written text and image of factual text. Thus, their critical reading skills did not run smoothly. The finding of the classroom observation is relevant to the result of reading test.

Due to in the first cycle most students had not reached the learning outcome significantly; the second cycle of the classroom action research was conducted. After conducting deep analysis of the problems found at the first cycle, the stages of classroom action research of the second cycle were carried out similar to the first one. In this cycle, the teaching-learning process of critical reading was about factual texts but the students got different text in evaluation. Based on the data gained from the second reading test, eighty percents of all students were able to achieve scores more than eighty. It indicates that the result showed the significant difference, compared with that of the first cycle. Moreover, the results gained from classroom observations and questionnaire showed that the students were able to comprehend the factual texts easily. Moreover, they were capable of integrating meaning of written text and image. Therefore, the padlet applicationis effective in fostering college students' critical reading. The application facilitated students to construct the meaning of factual texts easily and read the factual text critically. 
Regarding the second research question discussing the strengths and the weaknesses of padlet application in fostering college students' critical reading skill, the results gained from all data collections in the first and second cycle showed that the implementation of padlet application in fostering students' critical reading skill has some strengths, such as it makes students read the text clearly and completely, makes students active learners because it is learning by doing; minimizes the ambiguity in constructing meaning of texts and images, develops students' critical reading and critical thinking, and makes teaching and learning activities run more effectivly and efficiently. Meanwhile, some weaknesses of padlet application in fostering collecge students' critickal reading skill cover the students having lower achievement have some troubles in conducting critical reading; and the classroom having limited internet access cannot implement the padlet application smoothly.

\section{CONCLUSION}

After discussing the findings from the data gained from the reading tests, classroom observations, and questionnaires, the researcher derives the following conclusion. Regarding the first research question exploring the effectiveness of padlet application in fostering students' critical reading skill, the findings show that the implementation of the padlet application had fostered college students' critical readings skill significantly. It can be seen from their achievements in critical reading test in the second cycle in which more than eighty percent of all students reached the learning outcomes. Their scores in critical reading were more than eighty. In this case, they were capable of integrating meaning of written text and image. Moreover, the padlet application facilitated students to construct the meaning of factual texts easily and read the factual text critically. By implementing the padlet application in critical reading periodically supported by college students' previous knowledge; reading skills and reading comprehension, their critical reading skill improve.

Regarding the second research question discussing the strengths and the weaknesses of padlet application in fostering college students' critical reading skill, the results gained from all data collections indicate the implementation of padlet application in critical reading makes students read the text clearly and completely, makes students active learners because it is learning by doing; minimizes the ambiguity in constructing meaning of texts and images, develops students' critical reading and critical thinking, and makes teaching and learning activities run more effectivly and efficiently. However, the padlet application make the students having lower achievement have some troubles in conducting critical reading; and the classroom having limited internet access cannot implement the padlet application smoothly.

\section{REFERENCES}
Alderson, J., \& Bachman, F. (2000).Assessing reading. Cambridge: Cambridge University Press.

Chaffee, J., McMahon, C., \& Stout, B. (2002). Critical Thinking, 
BAHTERA: Jurnal Pendidikan Bahasa dan Sastra, Volume 17 Nomor 1 Januari 2018 http://journal.unj.ac.id/unj/index.php/bahtera/

P-ISSN : 0853-2710

E-ISSN : 2540-8968

Thoughtful Wiring. New York: Houghton Mifflin Company.

Dawson, C. (2009). Introduction to Research Methods: a practical guide for anyone undertaking a research project $\left(4^{\text {th }}\right.$ ed). Oxford: How to Books Ltd.

Dornyei, Z. (2003). Questionnaires in Second Language Research. New Jersey: Lawrence Erlbaum Associates, Inc.

Dornyei, Z. (2007). Research Methods in Applied Linguistics, Quantitative, Qualitative and mix methodology. Oxford: Oxford University Press.

Emilia, E. (2010). Teaching Writing.Developing Critical Learners. Bandung: RIZQI Press.

Green \&Skukauskaite. 2008. Becoming Critical Readers: Issues in Transparancy, Representation, and Warranting of Claims. Educational Researcher. Volume 37: 1. January 2008.http://er.aera.net. DOI: 10.3102/0013189X08314828.

Accessed on December 2016.

Kurland, D. 2000. What is Critical

Reading? Retrieved from

http://www.criticalreading.com/criti cal readin/kurlkan-What Is Critical Reading.htm

Labaw, P. J. (1980). Advance Questionnaire Design. Cambridge.

Makin, M. \& Whitehead, L. 2004. How to Develop Children's Early Literacy: A Guide for Professional Carers and Educators. London: SAGE Publication Company.

Marschall, S. \& Davis, C. 2012.A Conceptual Framework for Teaching Critical Reading to Adult College Students.Adult Learning. Volume 23:2. 2012. http://rel.sagepub.com/journalsPer mission.nav.www.sagepublications. com. Accessed on December 2016.

Mayer, E. (2006). Teachers' attitude to critical literacy: multiple voice.

Mochinsky, T. (2008).Critical pedagogy and everyday classroom.Canada springer.

Morgan, W. (1997). Critical literacy in the Classroom: the Art of Possible. London: Rutledge.

Nunan, David. (2002). Research Methods in Language learning. Shanghai: Shanghai Foreign Language

Reid. (2012). Gaps and silences: perception, practice, and policy of critical literacy, critical theory. Journal of critical literacy.Retrived on March 2016.

Thomas, R. M. (2003). Blending Qualitative and Quantitative Research Methods in Theses and Dissertations. California: Corwin Press. Inc.

Wallace, Catherine. (2003). Critical Reading in language Education. New York: Palgrave Macmillan.

Walz, J. (2001). Critical reading and the internet.The French Review, 74(6), 1193-1205.

Yu, Jinhong. 2015. Analysis of Critical reading Strategies and Its Effect on College English Reading. Theory and Practice in Language Studies. Volume 5: 1. January 2015. http://dx.doi.org/10.17507/tpls.050 1.18. Accessed on October 2016.

Zabihi, R. \&Pordel, M. 2011. An Investigation of Critical Reading in Reading Textbooks: A Qualitative Analysis. International Education Studies. Volume 4: 3. August $2011 . \quad$ www.ccsenet.org/ies. doi:10.5539/ies.v4n3p80. accessed on March 2017. 
BAHTERA: Jurnal Pendidikan Bahasa dan Sastra, Volume 17 Nomor 1 Januari 2018 http://journal.unj.ac.id/unj/index.php/bahtera/

P-ISSN : 0853-2710

E-ISSN : 2540-8968 